\title{
Attributes determining store loyalty: a study of the supermarket sector
}

\author{
José Marcos Carvalho Mesquista ${ }^{\dagger}$ \\ Faculdade Novos Horizontes \\ José Edson Lara \\ Federal University of Minas Gerais
}

\begin{abstract}
Based on the observance that rivalry among retailers has increased sharply in recent decades, with a growing number of stores and consequently more options for consumers, the aim of this study was to discover what attributes are valued by consumers in their choices on where to shop. The specific focus is on the causal relationships between the attributes offered by stores, grouped into two constructs, called "what" and "how" factors, with the latent variable being "store loyalty". The study is based on a field survey conducted in supermarkets in the city of Belo Horizonte, Minas Gerias, in which 300 shoppers were interviewed. The data were analyzed through structural equation modeling. The results identified positive and statistically significant relations between the attributes offered by the retailers and the respective constructs, and moderate adjustment of the structural model, indicating causal bonds between loyalty and its antecedent constructs.
\end{abstract}

Keywords: retailing, supermarkets, consumer behavior, loyalty, relationship marketing

\footnotetext{
Received in 05/29/2007; revised in 06/022007; accept in 10/292007.

Corresponding authors:

+ Professor Colaborador da Faculdade Novos Horizontes.

¥ Professor Adjunto da Universidade Federal de

Rua Carangola, no. 347/103, Belo HorizonteMinas Gerais.

$M G$ - Brazil - CEP 30.330-240

Rua Curitiba, no. 832, 1207, Belo Horizonte-

e-mail: jose.mesquita@unihorizontes.br

MG - Brazil - CEP 30170-120.

e-mail:jedson@face.ufmg
}

Editor's note: This paper was accepted by Alexsandro Broedel Lopes. 


\section{INTRODUCTION}

The recent growth of the retail sector in Brazil has been impressive, especially after the
introduction of the Real Plan and its consequent monetary stability. In this respect,
the supermarket sector stands out, as shown by the data presented in Table 1 .

Table 1. Brazilian Supermarket Sector. Selected Indicators. 1998-2006

\begin{tabular}{|c|c|c|c|c|c|c|c|c|c|}
\hline & 1908 & 1999 & 2000 & 2001 & 2002 & 2001 & 2004 & 2005 & 2006 \\
\hline Number of stores & 51502 & 53313 & 61259 & 69396 & 68907 & 71372 & 71951 & 72884 & 73695 \\
\hline $\begin{array}{l}\text { Annual tumover } \\
\text { (RS billion) }\end{array}$ & 56.8 & 61,5 & 69.2 & 74.2 & 81,7 & 89.3 & 98.7 & 118.5 & 124,1 \\
\hline $\begin{array}{c}\text { Share of GDP } \\
(\%)\end{array}$ & 6,2 & 6,3 & 6,3 & 6.2 & 6,1 & 5,7 & 5.5 & 5,5 & 5,3 \\
\hline Number of direct johs & 666752 & 670086 & 701622 & 710743 & 718631 & 739846 & 788268 & $\begin{array}{c}80092 \\
2\end{array}$ & 838047 \\
\hline $\begin{array}{l}\text { Sales area } \\
\text { (million m²) }\end{array}$ & 12,7 & 13.1 & 14.3 & 15.3 & 15.9 & 17.9 & 18.1 & 18,4 & 18.9 \\
\hline Number of check-outs & 125867 & 135914 & 143705 & 156022 & 157446 & 163216 & 166503 & $\begin{array}{c}16958 \\
3\end{array}$ & 175621 \\
\hline
\end{tabular}

Source: SuperHiper (2007).

Source: SuperHiper (2007).

Except for share of GDP, all the other indicators grew over the period analyzed. The growth rates were, in decreasing order: yearly turnover, $118.49 \%$; sales area, $48.82 \%$; number of stores, $43.09 \%$; number of check-outs, $39.53 \%$ and number of direct jobs, $25.69 \%$. These data reflect not only the sector's vigorous growth, but also the importance of this activity in the national economy.

This performance can be partly credited to a series of changes that have been occurring in the Brazilian economy in recent years, which have incorporated a large contingent of people into the consumer market who were previouslyat the margins of the system.

The greater number of establishments means more shopping options from the consumer's standpoint. For companies, however, this heightens the competitive environment, and the attraction of new customer and keeping them faithful becomes extremely challenging.

Besides this, in the current context of monetary stability, there is no longer any need for people to rush to make household purchases right after receiving their wages so that their money will not be corroded by galloping inflation. This allows them to make more visits to retail establishments, with reduction of the average ticket. According to the trade publication Gôndola (2005), the average number of monthly visits rose from 2.0 to 4.7.

Because of this new scenario, it has become more important to study the behavior of consumers, who are now faced with more shopping options both in terms of products and stores.

This study aims to evaluate what attributes are valued by consumers in choosing the retail establishment where they shop and the causal relationship between the presence of these attributes and their store loyalty.

The work is organized as follows: besides this introduction, containing the context and objectives, Section 2 presents the topics related to the retail segment in general and consumer loyalty in particular, Section 3 explains the methodology used, Section 4 presents the results, and Section 5 adds some final considerations, followed by the references and appendixes. 


\section{THEORETICAL BACKGROUND}

According to Howard-Sheth (1969) and Engel, Blackwell and Miniard (2000), shopping behavior can obey different criteria in relation to consumers' previous knowledge, characterizing a solution of an expanded (complex) problem, a solution of a limited problem and a solution of a routine problem. Moreover, shopping can be repeated, when a certain frequency occurs over time, motivating two distinct behaviors, according to Engel, Blackwell and Miniard (2000), the solution of a repeated problem and the making of a habitual decision. In the latter, decisions are made based on habits or routines formed by the consumer over time, generating brand loyalty orindifference.

On the matter of choosing an establishment where to make frequent purchases, such as household products, aspects of the retail segment must be analyzed.

According to Parente (2000, p. 22), "retailing consists of all the activities included in the process of selling products and services to serve a personal need of the end consumer." It differs from wholesaling because in the latter the customers are institutional, which buy products to resell them or to use them as inputs for their activities. Wholesalers play an intermediary role, uniting producers and consumers. Levy amd Weitz (2000) classify the retailer as a merchant that sells products and services for personal use of consumers or their family members, being the final commercial enterprise in linking manufacturers with consumers. Las Casas (2000) affirms that retailing is the commercial activity responsible for providing merchandise and services desired by consumers.

According to the form of selling, retailing can be classified into store and non-store retailing (direct marketing, direct sales and virtual stores). After this brief description of the retail segment, the task now is to understand how consumers make their choices as to establishments.

As proposed by some models of consumer behavior, there are five steps in the decision process: recognition of the need; search and evaluation of the alternatives; buying; and postpurchase experience, according to Engel, Blackwell and Miniard (2000), Sheth, Mittal and Newman (2001) and Solomon (2002).

In the case of retail shopping, the attributes guiding the search and evaluation step vary according to the category of products or type of store, but can be summarized into variables that compose the retail mix, according to Engel, Blackwell and Miniard (2000), Levy and Weitz (2000) and Parente (2000), as shown in the chart below. 
CHART 1. Attributes to evaluate retailers.

\begin{tabular}{ll}
\hline \multicolumn{1}{c}{ Variable } & \multicolumn{1}{c}{ Attributes } \\
\hline Product mix & Variety - range and depth \\
& Quality of products \\
& Exclusivityof style and design \\
\hline Presentation & Layout, departmentalization and display mix \\
& Decoration and atmosphere \\
& Visual communication and signage \\
& Comfort \\
\hline Price & Product prices \\
& Product cost/benefits \\
& Period and form of payment \\
\hline Promotion & Advertising \\
& Point of sale promotions \\
& Fidelity programs \\
\hline Sales staff & Speed of service \\
& Engagement and courtesy of the sales staff \\
& Technical qualification of the stales staff \\
& Services offered \\
\hline Point and location & Proximity \\
& Ease of access \\
& Complementation with other stores \\
\hline
\end{tabular}

Source: Parente (2000, p. 124).

It can be seen that there are various choice options suggested, involving not only the product, but also: services that facilitate buying; services that make buying more pleasant; financial attributes, which facilitate or enable buying; means of disclosing the establishment; and location. Therefore, the choice by consumers can be made according to what they judge necessary or convenient, and the retailer must be attentive to customers' preferences to meet their objectives.

Based on the list of attributes above, consumers choose the retail establishments where they will shop, and as suggested by Mesquita and Lara (2004), when the supply of attributes corresponds to the consumer's expectations, there is a high probability of repeat business. In other words, to the extent that the needs of customers are satisfied, their relationship with the retail establishment will be one of repeat trade, meaning the existence of a type of loyalty.

Brand loyalty is one of the most hotly studied themes these days, but various concepts still need to be examined in greater theoretical depth, despite the considerable advances already made.

According to Jacoby and Kyner (1973), brand loyalty is a special form of repeat buying and can be defined in terms of six collectively necessaryand sufficient conditions.

The first of these is that loyalty must be biased, that is, not random, in which case it becomes impossible to influence and outcome. The second refers to the behavioral response, that is, there must be determination of the actual buying behavior, not just an orally expressed intention to buy. The third regards the duration in time, involving purchases repeated more than once. The fourth affirms that the decision is made by a unit, not necessarily by a single person, which results in an important distinction, since often the decision-maker differs from the person who actually makes the purchase. The fifth concerns the loyalty to one or more brands chosen in a universe of many. The sixth condition suggests that loyalty is fruit of a process of evaluation, in which various brands are compared and one or more of them are chosen for representing the optimal choice. In this sense, the optimal choice is that which produces the best results, considering all the criteria involved in the decision. 
The above authors conclude that although they may appear the same, simple repeated purchases and brand loyalty are concepts that have different underlying dynamics, and thus the lack of one of the six conditions means there is no real brand loyalty. In this sense, it is fundamental to analyze consumers' thinking, not only what they actually purchase.

In this line of reasoning, Dick and Basu (1994), cited in Sheth Mittal and Newman (2001), suggest a classification of loyalty based on attitude and behavior components, resulting in four categories: true loyalty, latent loyalty, false loyalty and no loyalty. True loyalty is a combination of strong attitude and behavior, that is, besides frequently repeated purchases, the consumer has a commitment to the brand. Latent loyalty results from a combination of weak behavior and strong attitude, indicating low repeat purchase behavior, despite the favorable attitude, a situation characterized by barriers that impede making the purchase, such as inaccessible price. False loyalty is that which combines strong behavior with weak attitude, that is, although there is no commitment, there is repeat buying, explained by incentives such as low price. Finally, there is the category of no loyalty, representing the situation where there is neither repeat buying nor favorable attitude.

Faced with these variables included in the analysis of loyalty, Oliver (1999), presents another classification scheme, based on phases of loyalty:

- Cognitive loyalty: This is the phase of loyalty where the information available to the consumer about a brand's attributes indicates one brand is preferable to its alternatives. The cognition can be based on previous knowledge, observation or recent experience.

- Affective loyalty: In this phase there is a favorable attitude to the brand, based on cumulatively satisfying usage experiences.

- Conative loyalty: In this phase, a deep commitment to purchase the brand repeatedly has developed.

- Action loyalty: In this phase, strong desire and commitment are transformed into readiness to act, generating an urge in the consumer even to overcome obstacles to achieve the desired purchase.

Since there are obstacles to gaining customers' loyalty, due to various motives, such as multi-brand loyalty, idiosyncratic behaviors or incentives of competitors, Oliver (1999) deepens the analysis by means of a classification scheme based on two dimensions: personal fortitude and social support.

The intersection of these dimensions results in four cells, containing loyalty strategies. The first and weakest form of loyalty, called product superiority, combines low social support with low individual fortitude. The second reflects a consumer who has high fortitude, but little social support, revealing one who does not want to be courted by other brands. For this reason, this phase is called self-isolation. The third cell results from the intersection of low fortitude and high social support, and is called village envelopment, indicating that the consumer is protected from external influences and nurtured to consume a product, receiving frequent information and updates. Finally, there is the combination of high personal fortitude and high social support, defined as immersed self-identity, indicating a consumer who seeks participation in the social environment because it is consistent with and supports his or her self-concept. In other words, the consumer firmly desires to be associated with the product or service, joins the social environment knowing that it supports this association, and in extreme situations, is rewarded for this support. The author calls this situation final loyalty.

To reach this type of loyalty, five conditions are necessary:

- The product must have a unique configuration that makes it desirable.

- An identifiable and profitable segment of the company's customers must consider the product desirable. 
- The product must be the object of adoration, at least among the portion of possibly loyal customers.

- The product must be able to be included in a social network, so that the consumer only feels part of the village if somehow connected.

- The company must be willing to invest to create, popularize and maintain the village.

If the organization does not manage to achieve all these conditions, it should be content just to satisfy its customers, because maximum loyalty will be unattainable. Besides this, in many cases the changing conditions of the economy hinder winning customer loyalty.

Because it involves frequent purchases, with low involvement, acquisitions of domestic products do not tend to generate the final loyalty proposed by Oliver (1999), but rather only some type of conative loyalty, where there is merely a strong desire to repeat the process. Therefore, for organizations in this category, gaining customer satisfaction and thus creating a certain degree of inertia in the direction of repeat buying, is enough.

The matter of satisfaction itself is the subject of an extensive literature, with many works not only proposing models to measure consumer satisfaction, but also reporting empirical studies to do this in practice, and to relate its importance with organizational performance.

Farias and Santos (2000) affirm that customer satisfaction is characterized as a dimension that all organizations seek, because of its direct relation with brand loyalty, repeat buying, positive word-of-mouth, profitability and market share. Since the environment in which customer satisfaction occurs is dynamic, it is imperative, both in academic and management terms, to include new variables in the analysis, providing constant updating and enrichment of the theory and practice.

According to Oliver (1981), satisfaction can be understood as the inherent surprise upon acquiring a product or the experience of consuming it, that is, it is essentially the psychological state resulting when the emotion contained in the discomfirmed expectation is combined with the consumer's first impressions of the consumption experience. When dealing with purchases at retail establishments, the formation of expectations, disconfirmation and satisfaction can be understood in three dimensions: satisfaction with the store, satisfaction with the product and satisfaction with the response to any complaints. In other words, at all the stages, expectations can be created, disconfirmations encountered and levels of satisfaction created. Consumers' expectations regarding retailers normally include attributes related to the product mix, services, clientele, physical installations, conveniences, store atmosphere and promotional campaigns.

Disconfirmation is the mental comparison between the real state of a situation with its anticipated probabilit. If reality is worse than expected, the disconfirmation will be negative, while if reality is better than expected, the disconfirmation will be positve. Finally, if reality is just as expected, the disconfirmation will be zero.

Oliva, Oliver and MacMillan (1992) evaluate the relationship between satisfaction and loyalty, affirming that it is nonlinear, meaning that there are limits on the level of satisfaction beyond which loyalty varies suddenly, and that behavior follows satisfaction, i.e., a single case of high satisfaction or dissatisfaction is not likely to generate changes in loyalty.

Oliver (1999), also analyzing the relationship between satisfaction and loyalty, concludes that the transformation of the former into the latter is like the transformation of a caterpillar into a butterfly: once the metamorphosis has been made, the only link between them is the common origin.

Specifically focusing on the retail segment, Westbrook (1981) claims that satisfaction with a store can be measured by the following indicators: attentiveness of the sales staff; 
amiability of the sales staff; number of salespersons; courtesy of the sales staff; attractiveness of the store's interior; layout and space availability; ease of finding products; store cleanliness; mix of the different departments; quality of the goods sold; availability of merchandise; product variety; value received for the money spent; level of currency regarding fashion trends; willingness to exchange products or refund money; amiability in making repairs; credit availability and billing procedures; hours of operation; location; other shoppers; prices; promotions and advertising.

Prado and Marchetti (1996, 1996a and 1997) specifically analyze customer satisfaction with supermarkets. They state that considering the new realityimposed on businesses, dictated by the changing Brazilian economic context, supermarkets are exposed to a high level of competition. Therefore, it becomes fundamental to monitor customer satisfaction as a way to stand out from the competition. The more satisfied customers are, the greater will be their loyalty, meaning better sales performance and higher profits.

The authors evaluate the dimensions of service excellence in supermarkets, based on data collected in the Curitiba metropolitan region in the state of Paraná and construct a measurement scheme with 19 items, distributed in five dimensions. The first dimension refers to the services provided at the check-out, involving questions such as: modern equipment enabling short waiting times; equipment causing fewer errors; the existence of express checkouts for customers with few items; and clearly marked types of check-outs. The second dimension is related to the supermarket atmosphere, listing which aspects make customers feel good inside the store: airy and well-ventilated ambient; freshness of perishable products; variety of products; ease of finding products; lighting of the products; and size of the physical space. The bakery services offered correspond to the third dimension and relate to the variety, taste (or in-store smell) and display of the products. The fourth dimension refers to the attentiveness of the sales staff, both the cashiers and people available to answer questions. Finally, there is the dimension relative to meat and cold cuts, with the important aspects being: display of the products; freshness; appearance; andquality.

Révillion (2000) also evaluates customer satisfaction with supermarkets, identifying three dimensions responsible for satisfaction. The first, called comfort and convenience, is composed of the indicators: presence of a bagger; different payment options; store cleanliness; decoration/design and modernity; and efficiency of the equipment. The second dimension is called internal organization, composed of the variables: organization of each section; quality of the meats, cold cuts and dairy products; range of imported products; supermarket technology; and visibility of product prices. The third dimension, called services, contains the indicators: ease of obtaining a store credit card; availability of bar code price readers; sales via telephone, fax or Internet; competence of the employees and services; and home delivery of groceries.

Souza and Leite (1997) state that the variables that supermarkets can control in treating their customers well are: line of products; decisions on sales area; location; store ambience and decoration; pricing policy; layout and merchandising decisions; promotional policy; communication within the supermarket; self-service; and additional services.

Regarding retail establishments in general, Sheth, Mittal and Newman (2001) affirm that loyalty results from two sets of factors, called "what" and "how". The first is determined by the variables quality of merchandise, variety of products, price and brands. The second is determined by the variables ease of self-selection, information and assistance in the store, convenience, resolution of problems and personalization.

From the above it can be held that choices of which supermarket to patronize tend to be made based on a type of loyalty, similar to the conative loyalty in the classification scheme 
of Oliver (1999), as long as the important attributes in the decision process are offered adequately. Therefore, we propose here the evaluation model presented in Figure 1, according to which the "shopping" and "services" factors determine "store loyalty".

The "shopping" and "services" constructs roughly correspond to the "what" and "how" factors and are composed of component indicators of the retail mix (Chart 1) and are measured by two variables: repeat buying and intention to buy again.

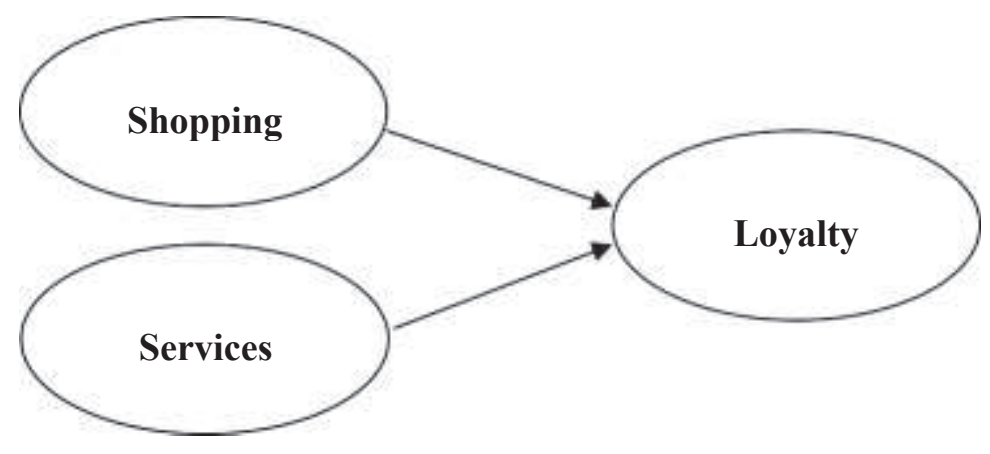

Figure 1. Model proposed to assess loyalty.

\section{METHODOLOGY}

The choice of the research method and techniques to be used should be made observing the proposed objectives of a work and also the reality to be examined. Thus, it is necessary to investigate what variables will be involved and what type of relationship is expected to be found.

Mattar (1997) and Malhotra (2001) suggest there are three categories of research: exploratory, descriptive and causal, according to the approach to be used regarding: the nature of the variables; the relationship among the variables; the objective and the degree in which the research problem is crystallized; the form used to gather the primary data; the scope in terms of amplitude and depth; the time dimension; the possibility of controlling the variables; and the environment where it is carried out.

The basic difference between descriptive and causal research rests in the objectives, or more specifically, the type of response sought. In descriptive research, the goal is to identify the profile of consumers, for example, what they buy, where they shop, how much they buy and when they shop. In causal research, the aim is to identify precisely the reasons for this behavior, that is, why consumers act in a certain way.

This work is causal, consisting of an empirical study of the supermarket sector. We collected the data in the city of Belo Horizonte, which we divided into three regions according to the average income of the population: high, medium and low (CDL, 2003), called group 1, 2 and 3, respectively. The criterion used for this classification was the proportion of inhabitants with average monthly income greater than or equal to 20 times the minimum monthly wage.

We chose segmentation based on income rather than social class because income better explains consumption of products without symbolic aspects, as is the case of food and household products, as stressed by Solomon (2002). Moreover, according to Kotler (2000), social class reflects, beyond income, indicators such as type of occupation, level of schooling and place of residence, with the latter automatically included in the analysis here because of the stratification of the sample. 
Based on the proposed division, we chose 20 supermarkets in each region, for a total of 60 stores, and applied questionnaires to five customers at each store, for a subtotal of 100 questionnaires per region and 300 in all. Our choice of the number of interview subjects followed the sampling techniques described in Malhotra (2001) and Stevenson (1981), and considered the recommendations on the number of observations necessary to apply the appropriate statistical techniques, as suggested by Hair et al. (2005) and Sharma (1996).

The questionnaire contained questions about the attributes considered important by the consumers in choosing where to shop, as described by Engel, Blackwell and Miniard (2000), Levy and Weitz (2000), Parente (2000), Prado and Marchetti (1996, 1996a and 1997), Révillion (2000) and Westbrook (1981). The answers were ranked on a scale of one to seven points.

Besides evaluating the various attributes, the questionnaires also sought to identify the profile of the consumers, aiming to confirm the convergence of the declared income with the average income of the region studied, and also to identify relevant factors for the research, such as: the domestic role performed by the shopper; family size; means of transportation used; reason for shopping; and level of schooling; among others.

The model was estimated with the structural equation modeling resource, according to procedures suggested by Hair et al. (2005) and Sharma (1996). The verification of the assumptions followed the orientation of the above authors. To test the univariate normality of the data, we used the Kolmogorov-Smirnov and Shapiro-Wilks tests, and we evaluated the multivariate normality by the kurtosis statistic. The presence of atypical observations was identified based on the Mahalanobis squared distance.

Regarding the measurement model, we based our choice of the variables to compose the model on the statistical significance of the standardized coefficients. Regarding the structural model, we sought to evaluate its consistency based on various indicators, due to the variety of indexes suggested in the specific literature.

We measured the reliability of the constructs based on Cronbach's alpha and tested the convergent validity by means of confirmatory factorial analysis for each construct. To measure the discriminant validity, we carried out the process in two steps, as suggested by Bagozzi and Philips (1982). In the first, after selecting a pair of constructs, we estimated a confirmatory factorial with covariance between the constructs set at 1 . Then we estimated another confirmatory factorial, but with free variance. In the second step we calculated the difference between the chi-square statistics of each test, which had to be greater than 3.84 , the critical value for one degree of freedom at a $1 \%$ significancelevel.

\section{RESULTS AND DISCUSSION}

First we applied the control questions, related to the socio-demographic profile of the respondents, which are described in Table 2.

In all the groups, the women were in the majority, above $60 \%$, with men's representation greatest in the highest income group. Around $70 \%$ of the respondents were between 25 and 60 years old.

The declared income was in accordance with the geographic separation found in CDL (2003), showing that $99 \%$ of the respondents in group 3, 86.5\% in group 2 and $62.5 \%$ in group 1 received less than 10 times the minimum monthly wage ("minimum salary"). The breakdown of those receiving between 10 and 20 minimum salaries was $31 \%$ of group 1, 12\% of group 2 and $0.9 \%$ of group 3, while those receiving over 20 minimum salaries made up only $6.5 \%$ of group 1 and $1.5 \%$ of group 2 (none in group 3 ). 
Table 2. Supermarket Customers in Belo Horizonte, MG. Profile of Interview Respondents $(\%)$.

\begin{tabular}{|c|c|c|c|c|}
\hline Question & Category & Group 1 & Group 2 & Group 3 \\
\hline \multirow[t]{2}{*}{ Sex } & Male & 37 & 35.5 & 31.8 \\
\hline & Female & 63 & 64.5 & 68.2 \\
\hline \multirow[t]{4}{*}{ Age } & Up to 25 & 14 & 24 & 13.9 \\
\hline & 25 to 40 & 35 & 30.5 & 38.6 \\
\hline & 40 to 60 & 37 & 37 & 36.6 \\
\hline & Over 60 & 14 & 8.5 & 10.9 \\
\hline \multirow[t]{4}{*}{ Monthly income } & Up to 5 minimum salaries & 21.5 & 43 & 74.3 \\
\hline & 5 to 10 minimum salaries & 41 & 43.5 & 24.8 \\
\hline & 10 to 20 minimum salaries & 31 & 12 & 0.9 \\
\hline & Over 20 minimum salaries & 6.5 & 1.5 & 0 \\
\hline \multirow[t]{4}{*}{ Distance } & Up to $2 \mathrm{~km}$ & 53.5 & 61 & 65.8 \\
\hline & 2 to $4 \mathrm{~km}$ & 32.5 & 25.5 & 29.7 \\
\hline & 4 to $6 \mathrm{~km}$ & 8.5 & 6 & 3.5 \\
\hline & More than $6 \mathrm{~km}$ & 5.5 & 7.5 & 1 \\
\hline \multirow[t]{4}{*}{ Means of transportation } & Car & 58.5 & 36.5 & 31.7 \\
\hline & Taxi & 1 & 2 & 2.5 \\
\hline & Bus & 3 & 12.5 & 65.3 \\
\hline & Walking & 37.5 & 49 & 0.5 \\
\hline \multirow[t]{5}{*}{ Motive } & Stock exhausted & 71.5 & 61.5 & 61.9 \\
\hline & Received salary & 7 & 5.5 & 20.3 \\
\hline & Visitors/parties & 4 & 1.5 & 1 \\
\hline & Advertising & 10 & 29 & 15.8 \\
\hline & Others & 7.5 & 2.5 & 1 \\
\hline \multirow[t]{5}{*}{ Household members } & 1 & 4 & 5.5 & 3.5 \\
\hline & 2 & 24 & 24.5 & 23.3 \\
\hline & 3 or 4 & 59 & 46 & 47.5 \\
\hline & 5 to 8 & 12.5 & 23 & 23.2 \\
\hline & More than 8 & 0.5 & 1 & 2.5 \\
\hline \multirow[t]{2}{*}{ User } & No & 29 & 15 & 12.4 \\
\hline & Yes & 71 & 85 & 87.6 \\
\hline \multirow[t]{2}{*}{ Payer } & No & 23 & 18 & 18.3 \\
\hline & Yes & 77 & 82 & 81.7 \\
\hline \multirow[t]{5}{*}{ Frequency } & Daily & 13 & 9.5 & 6.4 \\
\hline & Weekly & 27.5 & 30.5 & 22.3 \\
\hline & Every two weeks & 29.5 & 26.5 & 30.7 \\
\hline & Monthly & 28 & 30 & 38.1 \\
\hline & Others & 2 & 3.5 & 2.5 \\
\hline
\end{tabular}

Regarding location, $53.5 \%, 61 \%$ and $65.8 \%$ of the respondents in groups 1,2 and 3, respectively, shopped at establishments within $2 \mathrm{~km}$ of their residence or place of work. These figures, when added to those of people traveling up to $4 \mathrm{~km}$, result in roughly $90 \%$ for group 3 and $80 \%$ for the other two groups. The data on means of transport showed that nearly $60 \%$ of those interviewed used their own car in group 1, a figure that fell to $36.5 \%$ for group 2 and $31.7 \%$ for group 3 .

Regarding the reasons for buying the products purchased, the main one by a wide margin was that they had run out of these items at home: $71.5 \%, 61.5 \%$ and $61.9 \%$ for groups 1,2 and 3. For group 3, the fact of having received their pay was also important, with $20.3 \%$ of respondents citing it, while advertising motivated $10 \%, 29 \%$ and $15.8 \%$ of groups 1,2 and 3 , respectively. 
By the number of people in the household, we verified that the families tend to be larger in groups 2 and 3, a profile that was repeated with division of roles, with a higher proportion of users and payers in these groups. Finally, the frequency of shopping was similar in groups 1 and 2, while in group 3 the main pattern was monthly.

The descriptive statistics of the variables on the questionnaire, according to the constructs to which they refer, are shown in Table 3.

Table 3. Store Lovaltv. Descriptive Statistics. Belo Horizonte -MG.

\begin{tabular}{lllcc}
\hline Variable & \multicolumn{1}{c}{ Construct } & \multicolumn{1}{c}{ Item } & Mean & SD \\
\hline Q1 & Services & Distance of the store from the home or place of work & 5.91 & 1.77 \\
Q2 & Shopping & Variety of products & 6.23 & 1.11 \\
Q3 & Shopping & Store presentation (internal visuals) & 5.40 & 1.56 \\
Q4 & Services & Speed of check-out & 5.86 & 1.41 \\
Q5 & Shopping & Prices & 6.23 & 0.97 \\
Q6 & Shopping & Ease of circulation in the store & 6.14 & 1.08 \\
Q7 & Shopping & Quality of the products & 6.55 & 0.87 \\
Q8 & Shopping & Placement of products in the store & 5.97 & 1.12 \\
Q9 & Services & Own parking & 4.11 & 2.63 \\
Q10 & Shopping & Availability of products & 5.93 & 1.28 \\
Q11 & Shopping & Store comfort (lighting, air conditioning) & 5.48 & 1.47 \\
Q12 & Services & Special sections (meat, fish, baked goods, produce, etc.) & 6.10 & 1.31 \\
Q13 & Services & Fidelity programs of the store & 2.39 & 1.97 \\
Q14 & Services & Payment with post-dated check & 3.63 & 2.56 \\
Q15 & Shopping & Sanitary installations of the store & 3.95 & 2.39 \\
Q16 & Services & Delivery services & 2.82 & 2.56 \\
Q17 & Shopping & Nearby conveniences (automatic teller machines, pharmacies, & \\
& & florists, etc.) & 3.56 & 2.43 \\
Q18 & Services & Payment with store credit card & 2.69 & 2.40 \\
Q19 & Services & Baggers & 4.15 & 2.57 \\
Q20 & Loyalty & Habit of shopping at the store & 5.84 & 1.36 \\
Q21 & Shopping & Quality of the perishable items & 6.37 & 1.00 \\
Q22 & Services & Hours of operation & 5.64 & 1.92 \\
Q23 & Services & Guarantee of lowest price & 3.53 \\
Q24 & Shopping & Internal and external security & 6.09 \\
Q25 & Loyalty & Intention to repeat shop & 6.35 & 1.29 \\
\hline
\end{tabular}

Figure 2 shows the model estimated to evaluate the relationship of the attributes offered by the supermarkets, the shopping and services constructs and store loyalty. It can be seen that the solution adopted contains a reduced number of variables, in relation to the questionnaire initially proposed. The indicators of the new constructs are:

Shopping: 2, 3, 6, 7, 8, 10, 11, 17, 21 and 24;

Services: 4, 14, 16, 19 and 23;

Loyalty: 20 and 25 . 


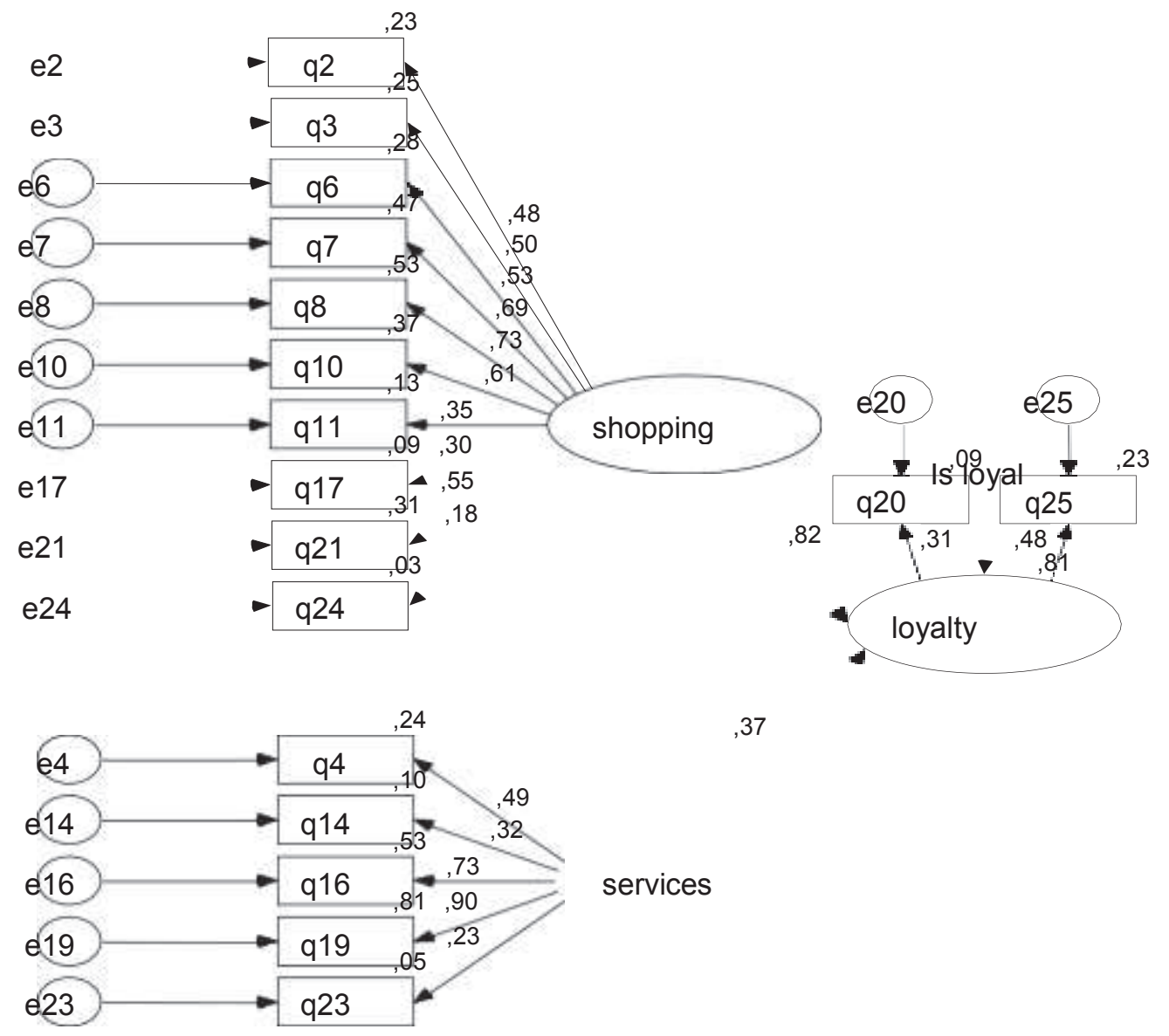

Figure 2. Model adopted to evaluate loyalty. Standardized weights.

These two dimensions, obtained from the exploratory analyses, are closely related to the "what" and "how" factors according to the proposal of Sheth, Mittal and Newman (2001). The "shopping" construct consists of variables related to the product itself $(2$, variety or products; 7, quality of products; and 21, quality of perishable items) and of those that facilitate shopping ( 3 , internal store presentation; 6 , ease of circulation; 8 , placement of products; 10 , availability of merchandise; 11, store comfort; 17, nearby conveniences; 24, internal and external security).

In turn, the "services" construct is composed of the variables regarding attentiveness of staff and quality of facilities (4, check-out speed; 16, delivery services; 19, baggers) and of variables related to economic questions (14, payment with post-dated check; 23, guaranteed lowest price by means of refund).

The "loyalty" construct was composed of the variables: 20, frequency of shopping at the store and 25, intention to repeat shop.

In other words, these constructs highlight the contemporary concerns regarding product quality, ease of shopping and economic terms.

Regarding verification of the assumptions, we found that the variables were not normally distributed, both from a univariate and multivariate standpoint. The correction routines commonly used, such as unit root extraction, inversion of values and transformation into logarithms, did not manage to correct this problem. On the other hand, the Mahalanobis 
square distance indicated the presence of 39 atypical observations, which we maintained in the database because we felt these data could characterize idiosyncratic behaviors of the consumers, and thus be relevant to the analysis.

Table 4 presents the model's indexes of fit. We chose generalized least squares as the estimation method because of its robustness in relation to deviations from normality.

Table 4. Overall measures of fit.

\begin{tabular}{lc}
\hline \multicolumn{1}{c}{ Index } & Value \\
\hline Measures of absolute fit & 334.156 \\
$\chi^{2}$ of the model estimated & 117 \\
Degrees of freedom & 0.00 \\
Significance & 0.869 \\
Goodness of Fit Index (GFI) & 0.079 \\
Root Mean Square Error of Approximation (RMSEA) & \\
Measures of incremental fit & 0.828 \\
Adjusted Goodness of Fit Index (AGFI) & 0.828 \\
Tucker-Lewis Index (TLI) & 0.869 \\
Normed Fit Index (NFI) & 2.856 \\
Measures of parsimonious fit & \\
Normed $\chi^{2}$ &
\end{tabular}

The model's overall measures of fit are outside the ideal limits. The chi-square statistic of the likelihood ratio has a 0.00 level of significance, so it acts in the sense of disqualifying the model, because the ideal would be failure by rejection of the test. The goodness of fit index (GFI) is a bit below the upper limit of 1 and the root mean square error of approximation (RMSEA) is within the maximum desirable limit of 0.08 . Regarding the incremental fit, the Tucker-Lewis index (TLI), the normed fit index (NFI) and the adjusted goodness of fit index (AGFI) are slightly below the minimum of 0.90 . Regarding the parsimonious fit, the normed chi-square index is below the more ample value of 5 and a bit above the more conservative limit of 2 . Given the sensitivity of some tests to the sample size and the proximity of the values found to the desired ones, we believe the model has a moderate degree of fit, which permits continuing the analysis (HAIR et al., 2005; SHARMA, 1996).

The values relative to the measurement model are shown in Table 5. All the variables included in the model are significant at the $1 \%$ level, except for variable 24 , of the shopping construct, and variable 20 , of the loyalty construct, with $5 \%$ significance.

Table 5. Measurement model. Standardized weights.

\begin{tabular}{cccc}
\hline Latent variable & Variable measured & Standardized weights & "t" statistic \\
\hline Shopping & Q2 & $0.481^{* * *}$ & 5.481 \\
& Q3 & $0.497 * *$ & $\ldots$ \\
Q6 & $0.525^{* * *}$ & 4.935 \\
Q7 & $0.686^{* * *}$ & 5.748 \\
Q8 & $0.730^{* * *}$ & 6.326 \\
Q10 & $0.608^{* * *}$ & 5.661 \\
Q11 & $0.355^{* * *}$ & 4.507 \\
& Q17 & $0.298^{* * *}$ & 3.584 \\
Q21 & $0.554 * * *$ & 5.091 \\
Q24 & $0.175^{* *}$ & 2.054 \\
\hline Q4 & $0.490^{* * *}$ & 2.809 \\
& Q14 & $0.324 * * *$ & 2.765 \\
& Q16 & $0.728^{* * *}$ & 3.025 \\
\hline
\end{tabular}




\begin{tabular}{cccc}
\hline & Q19 & $0.902 * * *$ & 2.978 \\
& Q23 & $0.234 * * *$ & $\ldots$ \\
\hline Loyalty & Q20 & $0.306 * *$ & $\ldots$ \\
& Q25 & $0.483 * * *$ & 3.325 \\
\hline
\end{tabular}

...: not calculated because AMOS 5 sets the coefficient at 1 . Significance: $* * * 1 \%, * * 5 \%$.

The results of the validity and reliability of the measurement model are presented below. Regarding unidimensionality, the antecedent constructs of loyalty, "what" and "how" were conceived to be multidimensional in essence, and for this reason this evaluation was not necessary.

Table 6 shows Cronbach's alpha for the constructs. It can be seen that the values are above the minimum limit of 0.6 for the shopping and services constructs, but do not reach this lower limit for loyalty. Due to the inclusion of only two construct variables, we already imagined this result and made provision for that limitation.

Table 6. Reliability of the constructs. Cronbach's alpha.

\begin{tabular}{lcc}
\hline & Construct & Coefficient \\
\hline Shopping & & 0.757 \\
Services & & 0.649 \\
Loyalty & & 0.282 \\
\hline
\end{tabular}

Regarding convergent validity, as suggested by Bagozzi and Philips (1982), we estimated a confirmatory factorial for each construct included in the model, and then evaluated the statistical significance of the estimated weights, attaining significant results for all the observable variables included in the analysis, at a level of $1 \%$. However, it is impossible to estimate the confirmatory analysis for the loyalty construct, based on the weights of the measurement model, because that construct only contains two variables. The standardized coefficients of the confirmatory factorial analyses are shown in Table 7.

Table 7. Convergent validity. Confirmatory factorial analysis

\begin{tabular}{llcc}
\hline Construct & Variable & Coefficient & "t” statistic \\
\hline Shopping & Q2 & $0.578^{* * *}$ & 6.319 \\
Shopping & Q3 & $0.458^{* * *}$ & $\ldots$ \\
Shopping & Q6 & $0.626^{* * *}$ & 5.739 \\
Shopping & Q7 & $0.756^{* * *}$ & 6.333 \\
Shopping & Q8 & $0.694 * * *$ & 6.684 \\
Shopping & Q10 & $0.661 * * *$ & 6.163 \\
Shopping & Q11 & $0.416^{* * *}$ & 5.448 \\
Shopping & Q17 & 5.086 \\
Shopping & Q21 & 5.980 \\
Shopping & Q24 & $0.442 * * *$ & 4.351 \\
Services & Q4 & $0.681 * * *$ & 3.732 \\
Services & Q14 & $0.385 * *$ & 4.010 \\
Services & Q16 & $0.401^{* * * *}$ & 4.063 \\
Services & Q19 & $0.690^{* * *}$ & 4.025 \\
Services & Q23 & $0.878^{* * *}$ & $\ldots$ \\
\hline
\end{tabular}

...: not calculated because AMOS 5 sets the coefficient at 1 . Significance: $* * * 1 \%$.

Regarding the discriminant validity, whose results are shown in Table 8 , we carried out the test proposed by Bagozzi and Philips (1982), previously discussed. According to the values, there is discrimination between the constructs. 
Table 8. Discriminant validity. Difference between $\chi^{2}$.

\begin{tabular}{llccc}
\hline \multicolumn{1}{c}{ Construct A } & \multicolumn{1}{c}{ Construct B } & $\chi^{\mathbf{2}} \mathbf{1}$ & $\chi^{\mathbf{2} 2}$ & Difference \\
\hline Shopping & Services & 331.027 & 280.303 & 50.724 \\
Loyalty & Shopping & 202.378 & 152.351 & 50.027 \\
Loyalty & Services & 143.605 & 76.165 & 67.440 \\
\hline
\end{tabular}

The results of the structural model are shown in Table 9. The value of the "t" statistic indicates a $1 \%$ significance level for the coefficient between shopping and loyalty and 5\% for services and loyalty. Based on the set of results, it can be inferred there is a high causal link between the shopping and services constructs, as causes, and loyalty as the effect, with significant standardized coefficients and $80.6 \%$ of the variance explained. This indicates conative loyalty according to the scheme proposed by Oliver (1999), explained more by the "shopping" factor than by the "services" factor.

Table 9. Structural equation. Shopping, services and lovalty.

\begin{tabular}{ccccc}
\hline \multicolumn{1}{c}{ Table 9. Structural equation. Shopping, services and lovalty. } \\
$\begin{array}{c}\text { Latent } \\
\text { endogenous } \\
\text { variable }\end{array}$ & $\begin{array}{c}\text { Latent } \\
\text { endogenous } \\
\text { variable }\end{array}$ & Coefficients & "t' statistic & $\begin{array}{c}\text { Multiple squared } \\
\text { correlation }\end{array}$ \\
\hline Loyalty & Shopping & 0.818 & 3.287 & 0.806 \\
\hline
\end{tabular}

\section{FINAL CONSIDERATIONS}

In summary, it can be inferred that despite the moderate degree of fit of the overall model and the fact that some measures are below the desired minimum for measurement and structural models, there is a causal relationship between the constructs analyzed. Therefore, we believe the relation is adequate between the attributes that guide the consumer's choice of and loyalty to a particular retail establishment.

In other words, this ratifies the model's supposition that the consumer's choice will be made based on simplified procedures, and that store loyalty will result from the "what" and "how" factors, as suggested by Sheth, Mittal and Newman (2001), perhaps because shopping at supermarkets is routine in nature. Therefore, the result is in line with the scheme proposed, according to which the choice of retail establishment will be made by the offer of attributes deemed important for the particular shopping experience, and from the moment the presence of these attributes is confirmed, there will be a high probability of repeat patronage.

In relation to the works cited, the factors identified by Prado and Marchetti (1996, 1996a and 1997) as determinants of consumer satisfaction are: check-out services; supermarket atmosphere; bakery services; helpful attention; and offer of meat and cold cuts, with their respective indicators.

The factors evaluated by Révillion (2000) were: comfort and convenience; internal organization; and services.

The variables that can be controlled by supermarkets, aiming at good customer satisfaction, according to Souza and Leite (1997), are: line of products; area for sales; location; environment and decoration; pricing policy; layout and merchandising; promotions policy; communication; attentiveness in self-service; and additional services.

Even though they present different groupings, all these works contain quite similar variables to those identified in the present study, with the shopping construct covering the 
variables related to products and internal and external atmosphere, and the services construct covering variables related to attentive treatment and offer of financial facilities.

Therefore, we believe that in an environment of great rivalry, which makes it difficult to gain competitive advantages, understanding to what measure consumers desire and value the offer of various attributes is fundamental to the strategy of any retail establishment. In other words, some services offered can generate costs for the company without resulting in gains. On the other hand, offering those attributes that really are valued by consumers is able to generate satisfaction that can translate into loyalty.

Finally, some limitations of the study and suggestions for further research must be mentioned. First, the restriction of the study to the city of Belo Horizonte and the supermarket sector does not permit generalizations. Hence, there is a need to carry out similar studies in other geographic areas, and also in other retail segments, where the shopping behaviors may be different, particularly when involving the purchase of products with high symbolic value.

Besides, this, there are many models and ranking scales available to measure customer satisfaction and loyalty, each of them proposing a specific type of measurement. Thus, other studies, involving different methodologies, but that seek to examine the central aspects of the present study (conjugation of the retail mix with loyalty) could serve as tests for identification of relevant attributes, creation of scales and validation of results, making valuable academic contributions.

\section{REFERENCES}

BAGOZZI, Richard P.; PHILIPS, Lynn W. Representing and testing organizational theories: a holistic construal. Administrative Science Quartely, v.27, n.3, pp. 459-489. 1982.

CÂMARA DE DIRIGENTES LOJISTAS DE BELO HORIZONTE - CDL. Concentração de empresas por regional administrativa de Belo Horizonte. Belo Horizonte: 2003.

ENGEL, J. F.; BLACKWELL, R. D.; MINIARD, P. W. Comportamento do consumidor.

Rio de Janeiro: Livros Técnicos e Científicos Editora S.A., 2000.

FARIAS, S. A. de; SANTOS, R. C. Modelagem de equações estruturais e satisfação do consumidor: uma investigação teórica e prática. Revista de Administração Contemporânea, v. 4, n. 3, pp. 107-132, Sept.-Dec. 2000.

GÔNDOLA. Belo Horizonte: Associação Mineira de Supermercados. Year 11, n. 127, Oct. 2005.

HAIR, J. F. et al. Análise Multivariada de Dados. Porto Alegre: Bookman, 2005.

HOWARD, J. A.; SHETH, J. N. The Theory of Buyer Behavior. New York: John Wiley \& Sons, 1969.

JACOBY, J.; KYNER, D. B. Brand loyalty vs. repeat purchasing behavior. Journal of

Marketing Research, v. X, pp. 1-9, Feb. 1973.

KOTLER, P. Administração de marketing. 10th ed. São Paulo: Prentice-Hall, 2000.

LAS CASAS, A. L. Marketing de varejo. 2nd ed. São Paulo: Atlas, 2000.

LEVY, M.; WEITZ, B. A. Administração de varejo. São Paulo: Atlas, 2000.

MALHOTRA, N. K. Pesquisa de marketing: uma orientação aplicada. Porto Alegre:

Bookman, 2001.

MATTAR, F. N. Pesquisa de marketing. São Paulo: Editora Atlas, 1997.

MESQUITA, J. C. M., LARA, J. E. Investigação empírica sobre os atributos determinantes do comportamento do consumidor em compras freqüentes. In ANGELO, C.F. de e SILVEIRA, J. A. G.da. Varejo Competitivo. São Paulo: Saint Paul Editora, v. 9, 2004. 
OLIVA, T. A.; OLIVER, R. L.; MacMILLAN, I. C. A catastrophe model for developing service satisfaction strategies. Journal of Marketing, v. 56, pp. 83-95, July 1992.

OLIVER, R. L. Whence consumer loyalty. Journal of Marketing, v. 63, special issue, pp.

33-44. 1999.

OLIVER, R. L. Measurement and evaluation of satisfaction process in retail settings. Journal of Retailing, v. 57, n. 3, 1981.

PARENTE, J. Varejo no Brasil: gestão e estratégia. São Paulo: Atlas, 2000.

PRADO, P. H. M.; MARCHETTI, R. Dimensões da satisfação do consumidor em supermercados. ENANPAD 20, 1996.

PRADO, P. H. M.; MARCHETTI, R. A automação comercial e a satisfação do consumidor em supermercados. In ANGELO, C. F. de; SILVEIRA, J. A. G. da. Varejo competitivo. São Paulo: Atlas, 1996a.

PRADO, P. H. M.; MARCHETTI, R. Excelência em supermercados: a dimensão da satisfação do consumidor. Revista de Administração USP, São Paulo: v. 32, n 2, April-June 1997.

RÉVILLION, A. S. P. Satisfação do consumidor com o setor supermercadista: o caso de Porto Alegre. In ANGELO, C. F. de; SILVEIRA, J. A. G. da. Varejo competitivo. São Paulo: Atlas, v. 4, 2000.

SHARMA, S. Applied multivariate techniques. USA: John Wiley \& Sons, 1996.

SHETH, J. N.; MITTAL, B.; NEWMAN, B. I. Comportamento do cliente: indo além do comportamento do consumidor. São Paulo: Atlas, 2001.

SOLOMON, M. R. O Comportamento do consumidor: comprando, possuindo e sendo. 5th ed. Porto Alegre: Bookman, 2002.

SOUZA, F. M de; LEITE, A. P. R. Estratégias de marketing no setor supermercadista: um estudo exploratório. In ANGELO, C. F. de; SILVEIRA, J. A. G. da. Varejo competitivo. v. 2. São Paulo: Atlas, 1997.

STEVENSON, W. J. Estatística aplicada à administração. São Paulo: Atlas, 1981.

SUPERHIPER. São Paulo: Associação Brasileira de Supermercados, Year 33, May 2007.

WESTBROOK, R. A. Sources of consumer satisfaction with retail outlets. Journal of

Retailing, v. 57, n. 3, 1981. 